\title{
IRRIGATION WITH DOMESTIC WASTEWATER: A MULTIVARIATE ANALYSIS OF MAIN SOIL CHANGES ${ }^{(1)}$
}

\author{
Thomas Vincent Gloaguen ${ }^{(2)}$, Roberta Alessandra Bruschi Gonçalves ${ }^{(2)}$, \\ Maria Cristina Forti ${ }^{(3)}$, Yves Lucas ${ }^{(4)}$ \& Célia Regina Montes ${ }^{(5)}$
}

\begin{abstract}
SUMMARY
Irrigation with treated domestic sewage wastewater (TSE) is an agricultural practice to reduce water requirements of agroecossystems and the nutrient load impact on freshwaters, but adverse effects on soil chemical (salinization, sodification, etc.) and soil physical properties (alteration in soil porosity and hydraulic conductivity, etc.) have been reported. This study aimed to define some relationships among these changes in an Oxisol using multivariate analysis. Corn (Zea mays L.) and sunflower (Helianthus annuus L.) were grown for two years, irrigated with TSE. The following soil properties were determined: $\mathrm{Ca}^{2+}, \mathbf{M g}^{2+}$, $\mathrm{Na}^{+}, \mathrm{K}^{+}$and $\mathrm{H}+\mathrm{Al}$ contents, cationic exchangeable capacity (CEC), sum of bases (SB), base saturation (V), texture (sand, silt and clay), macro-, micro-, and cryptoporosity $\left(\mathrm{V}_{\mathrm{MA}}, \mathrm{V}_{\mathrm{MI}}\right.$ and $\left.\mathrm{V}_{\mathrm{CRI}}\right)$, water content at soil saturation $\left(\theta_{\mathrm{S}}\right)$ and at field capacity $\left(\theta_{\mathrm{FC}}\right)$, residual water content $\left(\theta_{\mathrm{R}}\right)$, soil bulk density $\left(d_{\mathrm{s}}\right)$, water dispersed clay $(\mathrm{WDC})$ and saturated hydraulic conductivity $\left(\mathrm{K}_{\mathrm{SAT}}\right)$. Factor analysis revealed the following six principal factors: Fine Porosity (composed of $\mathrm{Na}^{+}, \mathrm{K}^{+}$, WDC, $\theta_{\mathrm{R}}$, $\theta_{\mathrm{RFC}}$, and $\left.\mathrm{V}_{\mathrm{CRI}}\right)$; Large Porosity $\left(\theta_{\mathrm{S}}, \mathrm{d}_{\mathrm{s}}, \mathrm{V}_{\mathrm{MA}}, \mathrm{V}_{\mathrm{s}}\right)$; Soil CEC $\left(\mathrm{Ca}^{2+}, \mathrm{Mg}^{2+}, \mathrm{CEC}, \mathrm{SB}, \mathrm{V}\right)$; Soil Acidity $(\mathrm{H}+\mathrm{Al})$; and Soil Texture (factors 5 and 6). A dual pore structure appears clearly to the factors 1 and 2 , with an apparent relationship between fine porosity and the monovalent cations $\mathrm{Na}^{+}$and $\mathrm{K}^{+}$. The irrigation (with potable sodic tap water or sewage wastewater) only had a significant effect on Fine Porosity and Large Porosity factors, while factors 3 and 4 (Soil CEC and Soil Acidity) were correlated with soil depth. The main conclusion was a shift in pore distribution (large to fine pores) during irrigation with TSE, which induces an increase of water storage and reduces the capacity of drainage of salts.
\end{abstract}

Index terms: soil porosity, soil sodicity, factor analysis.

\footnotetext{
(1) Received for publication in September 2009 and approved in June 2010.

(2) Full professor, Centro de Ciências Exatas e Tecnológicas, Universidade Federal do Recôncavo da Bahia - CETEC/UFRB. Campus Universitário, s/n. CEP 44380-000 Cruz das Almas (BA). E-mails: tgloaguen@gmail.com; robertabruschi@gmail.com (3) Researcher, Instituto Nacional de Pesquisas Espaciais (INPE). E-mail: cristina.forti@cptec.inpe.br

(4) Full professor, Processus de Transfert et d'Echange dans l'Environnement, Université du Sud Toulon-Var ((PROTEE/USTV), França. E-mail: lucas@univ-tln.fr

(5) Full professor, Núcleo de Pesquisa em Geoquímica e Geofísica da Litosfera, Universidade de São Paulo (NUPEGEL/USP). Email: crmlauar@usp.br
} 


\title{
RESUMO: IRRIGAÇÃO COMÁGUA RESIDUÁRIA DOMÉSTICA: ANÁLISE MULTIVARIADA DAS PRINCIPAIS MUDANCAS NO SOLO
}

\begin{abstract}
A irrigação com águas residuárias tratadas (ART) é uma técnica utilizada na agricultura para reduzir as necessidades hidricas e o impacto da carga de nutrientes nos mananciais, porém vários efeitos negativos já foram registrados nas propriedades químicas (salinização, sodificação, etc.) e físicas do solo (alteração na porosidade e condutividade hidráulica do solo, etc.). Este estudo teve como objetivo definir, por meio de uma análise multivariada, interrelações entre essas mudanças em um Latossolo onde foram cultivados durante dois anos milho (Zea mays L.) e girassol (Helianthus annuus L.), irrigando com ART. Foram analisados: teores de $\mathrm{Ca}^{2+}, \mathrm{Mg}^{2+}, \mathrm{Na}^{+}, \mathrm{K}^{+}$e $\mathrm{H}+\mathrm{Al}$, capacidade de troca cationica (CTC), soma das bases $(S B)$, saturação por bases (V), textura (areia, silte e argila), macro-, micro- e criptoporosidade $\left(V_{M A}, V_{M I}\right.$ e $\left.V_{C R I}\right)$, umidades na saturação $\left(\theta_{S}\right)$ e na capacidade de campo $\left(\theta_{C C}\right)$, umidade residual $\left(\theta_{R}\right)$, densidade aparente do solo $\left(d_{s}\right)$, argila dispersa em água $(A D A)$ e condutividade hidráulica em meio saturado $\left(K_{S A T}\right)$. A análise revelou os seguintes seis fatores principais. Porosidade fina (composto por $\mathrm{Na}^{+}, \mathrm{K}^{+}, W D C, \theta_{R}, \theta_{C C}$ e $\left.V_{C R I}\right)$, Porosidade larga $\left(\theta_{S}, d_{s}, V_{M A}\right.$, $\left.V_{s}\right), C T C$ do solo $\left(\mathrm{Ca}^{2+}, \mathrm{Mg}^{2+}, \mathrm{CCC}, \mathrm{SB}, \mathrm{V}\right)$, Acidez do solo $(\mathrm{H}+\mathrm{Al})$ e Textura do solo (fatores 5 e 6). Uma estrutura de porosidade dupla apareceu claramente nos fatores 1 e 2 , mostrando relações nítidas entre Porosidade fina e os cátions monovalentes $\mathrm{Na}^{+}$e $\mathrm{K}^{+}$. O efeito da irrigação (utilizando água encanada sódica potável ou ART) foi somente significativo para os fatores Porosidade fina e Porosidade Larga, enquanto os fatores 3 e 4 (CTC do solo e acidez do solo) foram correlacionados com a profundidade do solo. A conclusão principal é a mudança da distribuição dos poros do solo durante a irrigação com ART (poros grossos para poros finos), o que leva ao aumento do armazenamento da água no solo e à redução da drenagem dos sais.
\end{abstract}

Termos de indexação: porosidade do solo, sodicidade do solo, análise de fatores.

\section{INTRODUCTION}

The use of domestic treated wastewater in agriculture is a good alternative of liquid waste recycling and avoids the use of potable water for irrigation, considering that the preservation of water resources is essential for the economical and ecological development of many countries, especially under semiarid climates as in the northeastern region of Brazil. However, it is however necessary to identify the best sustainable irrigation management due to possible undesirable effects on soil chemistry and physics caused by the specific characteristics of wastewater. Many studies have already reported the effects of irrigation with wastewater on soil agroecosystems, and $\mathrm{Na}^{+}$excess is generally indicated as a major problem (Bond, 1998; Jnad et al., 2001a; Gloaguen et al., 2007). Some studies compare the management of wastewater irrigation to irrigation with sodic water (Oster \& Shainberg, 2001; Jayawardane et al., 2001; Tillman, 2001). With regard to the soil physical properties, the main concerns are the reduction in infiltration (Meenner et al., 2001) and hydraulic conductivity (Magesan et al., 1999; Bagarello et al., 2006; Bhardwaj et al., 2007) as well as the changes in porosity (Jnad et al., 2001b). However, a significant connection between soil physical and chemical properties would be useful to determine the main effects of this irrigation practice on the soil quality. Multivariate analysis is a statistical tool that allows a reduction of the number of required properties and is also a support for the identification of key parameters. Factor analysis, used in this study, is a procedure designed to extract $\mathrm{m}$ common factors for a set of $\mathrm{p}$ quantitative variables $X$. For instance, Shukla et al. (2006) studied a large set comprising 21 soil properties and concluded that soil quality could be assessed by monitoring the soil organic $\mathrm{C}$ content only. The main objective of the present study was to separate the independent factors associated to the changes in soil quality during irrigation with sewage and sodic tap water.

\section{MATERIALS AND METHODS}

\section{Experimental site}

The study site was located in the town of Lins (São Paulo State, Brazil - 21 o $38^{\prime}$ '54 " S; $49^{\circ} 44^{\prime}$ '45 ” W), where the experimental plot $\left(4,500 \mathrm{~m}^{2}\right)$ was installed next to a domestic sewage treatment plant (Australian lagoon system) operated by Sabesp (Companhia de Saneamento Básico do Estado de São Paulo). The region is characterized by a mean monthly temperature ranging from 18 to $22{ }^{\circ} \mathrm{C}$, a dry winter 
(between June and September) and annual rainfall between 1,100 and $1,300 \mathrm{~mm}$. The soil was classified as a sandy loam dystrophic Oxisol.

The crops were chosen for the suitability for oil extraction. Two cycles (four months each) of maize (Zea mays L.) and two cycles of sunflower (Helianthus annuus L.) were irrigated for two years by a dripping system using two types of water: secondary treated sewage wastewater (plot SW) and sodic tap potable water (plot PW). The applied volume was $454 \mathrm{~mm}$ per cycle, with a total of $1,816 \mathrm{~mm}$ in the two years of experiment. A third plot, without cultivation or irrigation, was used as control soil in the initial stage, before irrigation (plot C). According to the classification of Ayers \& Wescot (1985), treated wastewater represents an intermediate risk of soil salinization and sodification (Table 1), whereas potable tap water (groundwater) was less saline but more sodic. Details about the experiment and water quality are available in Gloaguen et al. (2007).

\section{Soil physical properties}

Samples were collected at the end of the experiment, in $0.25 \mathrm{~m}$ soil layers, (from 0.125 to $1.875 \mathrm{~m}$ depth), with six replications per plot (48 samples per plot) for complete soil physical analysis. Water retention curves $\theta(h)$, where $\theta$ is the volumetric water content $\left(\mathrm{m}^{3} \mathrm{~m}^{-3}\right)$ and $h$ the matric potential $(\mathrm{m})$, were obtained in undisturbed core samples (height $2.4 \mathrm{~cm}$, three replications). The applied tensions were: $0.1,0.2,0.4,1,3,5,10,50$ and $150 \mathrm{~m}$, and the experimental data were fitted to the van Genuchten equation (van Genuchten, 1980), to obtain the empiric parameters $a, n$ and $m$. The equivalent diameter $d_{i}$ was calculated from the matric potential $h_{i}$ using the Laplace formula for capillary pores (Equation 1):

$$
\mathrm{h}_{\mathrm{i}}=-\frac{\sigma \cos \alpha}{\rho_{\mathrm{w}} \mathrm{gd}_{\mathrm{i}}}
$$

Table 1. Main chemical composition of irrigation waters (mean of 12 samples over two years)

\begin{tabular}{lcc}
\hline & $\begin{array}{c}\text { Treated sewage } \\
\text { effluent }\end{array}$ & $\begin{array}{c}\text { Sodic tap } \\
\text { water }\end{array}$ \\
\hline $\mathrm{pH}$ & 7.7 & 9.4 \\
$\mathrm{EC}\left(\mu \mathrm{S} \mathrm{cm}{ }^{-1}\right)$ & 736 & 408 \\
$\mathrm{SAR}$ & 10.4 & 19.8 \\
$\mathrm{Na}^{+}\left(\mu \mathrm{mol} \mathrm{L}^{-1}\right)$ & 5,577 & 4,483 \\
$\mathrm{~K}^{+}\left(\mu \mathrm{mol} \mathrm{L}^{-1}\right)$ & 322 & 19 \\
$\mathrm{Ca}^{2+}\left(\mu \mathrm{mol} \mathrm{L}^{-1}\right)$ & 195 & 42 \\
$\mathrm{Mg}^{2+}\left(\mu \mathrm{mol} \mathrm{L}^{-1}\right)$ & 100 & 10 \\
$\mathrm{Cl}^{-}\left(\mu \mathrm{mol} \mathrm{L}^{-1}\right)$ & 1,193 & 165 \\
$\mathrm{NH}_{4}^{+}\left(\mu \mathrm{mol} \mathrm{L}^{-1}\right)$ & 1,331 & 0.10 \\
$\mathrm{Alkalinity}(\mu \mathrm{mol} \mathrm{L}-1)$ & 7,136 & 4,775 \\
$\mathrm{DOC}(\mathrm{mg} \mathrm{L}-1)$ & 20.2 & 1.7 \\
\hline
\end{tabular}

EC: electric conductivity; SAR: sodium adsorption value; DOC: dissolved organic carbon. where $\sigma=$ surface tension $\left(\mathrm{N} \mathrm{m}^{-1}\right) ; \alpha=$ contact angle $\left.{ }^{\circ}\right) ; \rho_{\mathrm{w}}=$ specific water mass $\left(\mathrm{kg} \mathrm{m}^{-3}\right) ; g=$ acceleration of gravity $\left(\mathrm{m} \mathrm{s}^{-1}\right) ; d_{i}=$ equivalent pore diameter $(\mathrm{m})$.

The pore diameter volume ranging from $d_{1}$ to $d_{2}$ could therefore be calculated by the difference between the water contents $\theta_{1}$ and $\theta_{2}$, corresponding to $d_{1}\left(h_{1}\right)$ and $d_{2}\left(h_{2}\right)$, respectively.

Soil pore distribution was classified as follows: macropores with diameter $>50 \mu \mathrm{m}$ (water retained in soil with pressure $<6 \mathrm{kPa}$ ), micropores with diameter ranging from 0.2 to $50 \mu \mathrm{m}$ (pressure between 6 and $1,500 \mathrm{kPa}$ ) and cryptopores with diameter < $0.2 \mu \mathrm{m}$ (pressure $>1,500 \mathrm{kPa}$ ).

The water content at field capacity $\left(\theta_{F C}\right)$ was calculated using the equation $d^{2} h\left(\theta_{F C}\right) / \mathrm{d} \theta_{F C}{ }^{2}=0$, where $h(\theta)$ is a third-order polynomial equation $\left(r^{2}\right.$ always $>0.956$ in this study).

The saturated hydraulic conductivity soil $\left(K_{S A T}\right)$ was calculated from equation 2 , using the falling-head method (Klute \& Dirksen, 1986) in undisturbed soil cores (70 mm-diameter and height, three replications) sampled in the three plots and eight depths.

$$
K_{S A T}=\frac{a L}{A(\Delta t)} \ln \left(\frac{\Phi_{t 1}}{\Phi_{t 2}}\right)
$$

where $\Delta t=t_{2}-t_{1}=$ time interval of decrease of the total potential $\Phi_{\mathrm{t}}$ from $\Phi_{\mathrm{t} 1}$ to $\Phi_{\mathrm{t} 2} ; \mathrm{A}=$ section area of the soil core $\left(\mathrm{m}^{2}\right) ; \mathrm{L}=$ soil core height $(\mathrm{m}) ; \mathrm{a}=$ section area of the water column $\left(\mathrm{m}^{2}\right)$.

The pipette method (Klute \& Dirksen, 1986) was used to measure water-dispersed clay (WDC). Soil physical properties of the initial soil (plot C) are shown in table 2.

\section{Soil chemical properties}

Soil was sampled for chemical analysis at the end of the experiment from 0.125 to $1.875 \mathrm{~m}$ depth (eight soil layers), with six replications (48 samples per plot). The potential acidity $(\mathrm{H}+\mathrm{Al})$ was measured in calcium acetate solution $1 \mathrm{~mol} \mathrm{~L}^{-1}(\mathrm{pH}=7)$ by $\mathrm{NaOH}$ $0.025 \mathrm{~mol} \mathrm{~L}^{-1}$ titration and the $\mathrm{pH}$ was measured in $\mathrm{CaCl}_{2} 0.01 \mathrm{~mol} \mathrm{~L}^{-1}$. $\mathrm{Na}^{+}, \mathrm{K}^{+}, \mathrm{Ca}^{2+}$ and $\mathrm{Mg}^{2+}$ were extracted in $\mathrm{NH}_{4} \mathrm{Cl} 1 \mathrm{~mol} \mathrm{~L}^{-1}$, and analyzed by atomic emission spectroscopy (for $\mathrm{Na}^{+}$and $\mathrm{K}^{+}$) and flame absorption atomic spectroscopy (for $\mathrm{Ca}^{2+}$ and $\mathrm{Mg}^{2+}$ ). Soil chemical properties for the initial soil (plot C) are presented in table 3 .

\section{Statistics}

Mean values of the 144 datasets ( 48 samples per plot) were standardized to compare the properties. Logtransformations were necessary to normalize the data and homogenize variance. Correlation (Pearson coefficients) and factor analysis were performed for the 21 physical and chemical soil properties. Factor analysis (FA) was based on the correlation matrix, 
Table 2. Soil physical properties before experiment from 0 to $200 \mathrm{~cm}$ soil depth

\begin{tabular}{|c|c|c|c|c|c|c|c|c|c|c|c|c|c|}
\hline Depth & WDC ${ }^{(1)}$ & Sand & Silt & Clay & $d_{S^{(2)}}$ & $\theta_{S^{(3)}}$ & $\theta_{\mathrm{FC}}(4)$ & $\theta_{\mathrm{R}^{(5)}}$ & $V_{S^{(6)}}$ & $\mathrm{V}_{\mathrm{MA}}{ }^{(7)}$ & $\mathrm{V}_{\text {MI }}(8)$ & $V_{C R I}^{(9)}$ & $\mathbf{K}_{\mathrm{SAT}}{ }^{(10)}$ \\
\hline $\mathrm{cm}$ & 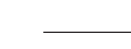 & $-\%$ & & - & $\mathrm{kg} \mathrm{dm}{ }^{-3}$ & & & & $-m^{3} m^{-}$ & & & & $\mathrm{mm} \mathrm{d}^{-1}$ \\
\hline 12.5 & 2.3 & 75 & 9 & 16 & 1.57 & 0.13 & 0.39 & 0.25 & 0.61 & 0.10 & 0.15 & 0.13 & 23 \\
\hline 37.5 & 0.7 & 72 & 7 & 21 & 1.55 & 0.13 & 0.41 & 0.26 & 0.59 & 0.10 & 0.19 & 0.12 & 86 \\
\hline 62.5 & 0.6 & 75 & 9 & 14 & 1.51 & 0.11 & 0.43 & 0.28 & 0.58 & 0.11 & 0.20 & 0.12 & 132 \\
\hline 87.5 & 2.3 & 73 & 7 & 20 & 1.56 & 0.13 & 0.39 & 0.25 & 0.61 & 0.10 & 0.16 & 0.14 & 153 \\
\hline 112.5 & 0.3 & 73 & 7 & 20 & 1.53 & 0.12 & 0.42 & 0.27 & 0.58 & 0.10 & 0.20 & 0.12 & 103 \\
\hline 137.5 & 1.0 & 75 & 9 & 16 & 1.53 & 0.12 & 0.41 & 0.26 & 0.60 & 0.10 & 0.17 & 0.12 & 124 \\
\hline 162.5 & 2.1 & 72 & 7 & 21 & 1.55 & 0.13 & 0.40 & 0.25 & 0.60 & 0.10 & 0.17 & 0.13 & 89 \\
\hline 187.5 & 0.3 & 73 & 8 & 19 & 1.50 & 0.12 & 0.43 & 0.28 & 0.57 & 0.10 & 0.20 & 0.12 & 119 \\
\hline
\end{tabular}

Table 3. Soil chemical properties before experiment, from 0 to $200 \mathrm{~cm}$ soil depth

\begin{tabular}{|c|c|c|c|c|c|c|c|c|}
\hline Depth & $\mathbf{H}+\mathbf{A l}$ & $\mathrm{Na}^{+}$ & $\mathbf{K}^{+}$ & $\mathrm{Ca}^{2+}$ & $\mathrm{Mg}^{2+}$ & $\mathrm{SB}^{(1)}$ & $\mathrm{CEC}^{(2)}$ & $\mathbf{V}^{(3)}$ \\
\hline $\mathrm{cm}$ & 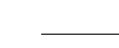 & - & 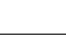 & $\mathrm{hol}_{\mathrm{c}} \mathrm{kg}$ & & & 5 & $\%$ \\
\hline 12.5 & 12.4 & 0.9 & 3.0 & 5.4 & 3.1 & 12.6 & 25.1 & 50.2 \\
\hline 37.5 & 12.7 & 0.7 & 2.5 & 3.8 & 1.8 & 8.9 & 21.7 & 41.2 \\
\hline 62.5 & 10.5 & 0.9 & 2.9 & 2.8 & 1.0 & 7.6 & 18.2 & 42.0 \\
\hline 87.5 & 8.1 & 0.9 & 3.5 & 3.5 & 1.2 & 9.1 & 17.7 & 51.3 \\
\hline 112.5 & 6.5 & 0.9 & 3.1 & 3.7 & 1.4 & 9.3 & 16.0 & 58.1 \\
\hline 137.5 & 6.6 & 0.9 & 3.6 & 4.1 & 1.8 & 10.4 & 17.0 & 61.0 \\
\hline 162.5 & 5.3 & 1.1 & 3.8 & 4.3 & 1.6 & 11.0 & 16.3 & 67.5 \\
\hline 187.5 & 5.4 & 1.1 & 4.6 & 4.5 & 1.7 & 12.4 & 17.8 & 69.8 \\
\hline
\end{tabular}

${ }^{(1)}$ SB: sum of bases. ${ }^{(2)}$ CEC: cationic exchange capacity. ${ }^{(3)} \mathrm{V}$ : base saturation.

using the Kaiser criterion (eigenvalue > 1); a varimax rotation was applied to the selected factors to emphasize high and low factor loadings. Analysis of variance was also performed to identify the effects of irrigation and soil depth on the factor scores. All these analyses were carried out using the software package Statistica (Statsoft v.7).

\section{RESULTS AND DISCUSSION}

\section{Univariate analysis}

Modifications in each soil property were expressed by the ratio between the value in the irrigated plot and plot $\mathrm{C}$ (initial soil), after irrigation with sewage wastewater or tap water (Figure 1). Variation was highest for $\mathrm{Na}^{+}$and $\mathrm{K}^{+}$(approximately 10 times larger in irrigated soils) and the opposed trends between the two alkaline metals indicated competition between them. Irrigation (with both SW and PW) also caused a high increase of clay dispersion and, consequently, an important decrease of $K_{S A T}$, possibly due to pore blockage by dispersed clays.

\section{Correlation analysis}

The discussion of the correlation coefficients (Table 4) was structured in: (a) correlations among

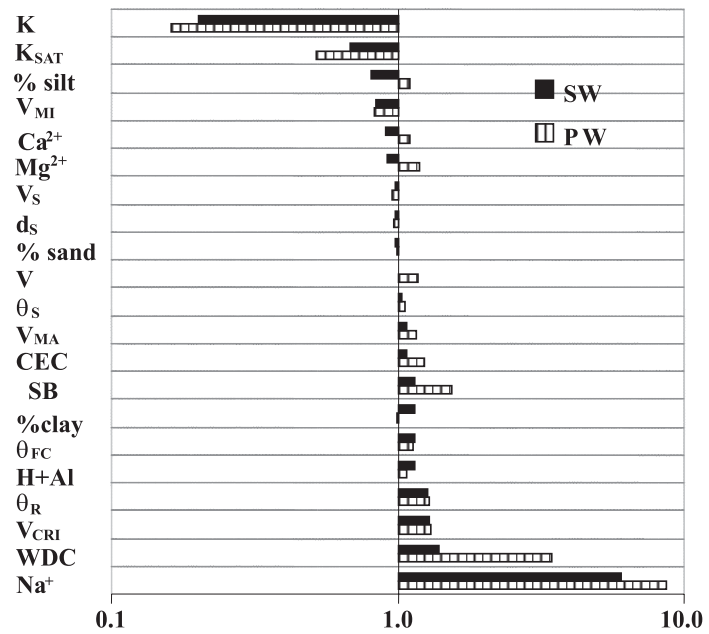

Figure 1. Ratios between soil properties values in non-irrigated soil (plot $\mathrm{C}$ ) and in soil irrigated with sewage wastewater water (SW) and potable water (PW)

chemical properties $\left(\mathrm{H}+\mathrm{Al}, \mathrm{Na}^{+}, \mathrm{K}^{+}, \mathrm{Ca}^{2+}, \mathrm{Mg}^{2+}, \mathrm{CEC}\right.$, $\mathrm{SB}, \mathrm{V})$, (b) correlations among physical properties $\left(\mathrm{V}_{\mathrm{S}}\right.$, $\mathrm{V}_{\mathrm{MA}}, \mathrm{V}_{\mathrm{MI}}, \mathrm{V}_{\mathrm{CRI}}, \mathrm{d}_{\mathrm{S}}, \theta_{\mathrm{R}}, \theta_{\mathrm{FC}}, \theta_{\mathrm{S}}, \mathrm{WDC}, \mathrm{K}_{\mathrm{SAT}}, \%$ clay, $\%$ silt, \% sand), and (c) correlations between physical and chemical properties. 
Table 4. Pearson correlation coefficients among physical and chemical soil properties

\begin{tabular}{|c|c|c|c|c|c|c|c|c|c|c|c|c|c|c|c|c|c|c|c|c|}
\hline & $\mathrm{H}+\mathrm{Al}$ & $\mathrm{Na}^{+}$ & $\mathbf{K}^{+}$ & $\mathrm{Ca}^{2+}$ & $\mathrm{Mg}^{2+}$ & SB & CEC & V & $\mathrm{K}_{\mathrm{SAT}}$ & WDC & $\%$ sand & $\%$ silt & $\%$ clay & $\theta_{\mathrm{R}}$ & $\theta \mathrm{s}$ & $\theta_{\mathrm{FC}}$ & ds & $\mathrm{V}_{\mathrm{s}}$ & $\mathrm{V}_{\mathrm{MA}}$ & $\mathrm{V}_{\mathrm{MI}}$ \\
\hline $\mathrm{H}+\mathrm{Al}$ & 1 & & & & & & & & & & & & & & & & & & & \\
\hline $\mathrm{Na}^{+}$ & -0.12 & 1 & & & & & & & & & & & & & & & & & & \\
\hline $\mathrm{K}^{+}$ & -0.15 & $-0.57^{*}$ & 1 & & & & & & & & & & & & & & & & & \\
\hline $\mathrm{Ca}^{2+}$ & -0.14 & $0.29^{*}$ & 0.02 & 1 & & & & & & & & & & & & & & & & \\
\hline $\mathrm{Mg}^{2+}$ & -0.02 & 0.23 & -0.05 & $0.81^{*}$ & 1 & & & & & & & & & & & & & & & \\
\hline SB & -0.18 & $0.77^{*}$ & -0.20 & $0.80^{*}$ & $0.70^{*}$ & 1 & & & & & & & & & & & & & & \\
\hline CEC & 0.17 & 0.73 & -0.26 & $0.75^{*}$ & $0.70^{*}$ & $0.94^{*}$ & 1 & & & & & & & & & & & & & \\
\hline V & $-0.60^{*}$ & $0.61^{*}$ & 0.02 & $0.69^{*}$ & $0.56^{*}$ & $0.85^{*}$ & $0.64^{*}$ & 1 & & & & & & & & & & & & \\
\hline $\mathrm{K}_{\mathrm{SAT}}$ & -0.11 & -0.22 & $0.31^{* * *}$ & $-0.59^{*}$ & $-0.72^{*}$ & $-0.49^{*}$ & $-0.53^{*}$ & -0.28 & 1 & & & & & & & & & & & \\
\hline WDC & -0.06 & $0.35^{* *}$ & $-0.44^{*}$ & 0.14 & 0.18 & 0.26 & 0.23 & 0.22 & -0.25 & 1 & & & & & & & & & & \\
\hline$\%$ sand & 0.02 & -0.10 & 0.07 & 0.14 & 0.11 & 0.02 & 0.03 & 0.04 & -0.09 & 0.17 & 1 & & & & & & & & & \\
\hline$\%$ silt & 0.07 & 0.02 & 0.03 & 0.06 & 0.16 & 0.09 & 0.11 & 0.10 & -0.09 & 0.22 & $-0.31^{* *}$ & 1 & & & & & & & & \\
\hline$\%$ clay & -0.08 & 0.06 & -0.08 & -0.17 & -0.23 & -0.10 & -0.12 & -0.12 & 0.15 & $-0.33^{* *}$ & $-0.56^{*}$ & $-0.61^{*}$ & 1 & & & & & & & \\
\hline$\theta_{\mathrm{R}}$ & -0.01 & $0.56^{*}$ & $-0.69^{*}$ & 0.05 & 0.16 & $0.31^{* *}$ & $0.31^{* *}$ & 0.23 & -0.25 & $0.62^{*}$ & 0.04 & -0.03 & -0.01 & 1 & & & & & & \\
\hline$\theta_{\mathrm{s}}$ & -0.10 & 0.08 & -0.18 & -0.25 & -0.19 & -0.13 & -0.16 & -0.11 & 0.20 & $-0.37^{*}$ & $-0.41^{*}$ & -0.14 & $0.46^{*}$ & -0.18 & 1 & & & & & \\
\hline$\theta_{\mathrm{FC}}$ & -0.06 & $0.49^{*}$ & $-0.72^{*}$ & -0.08 & -0.01 & 0.16 & 0.14 & 0.09 & -0.09 & $0.31^{* *}$ & -0.18 & -0.04 & 0.19 & $0.52^{*}$ & $0.58^{*}$ & 1 & & & & \\
\hline $\mathrm{ds}$ & 0.13 & 0.02 & 0.06 & 0.25 & 0.18 & 0.17 & 0.22 & 0.14 & -0.16 & $0.38^{*}$ & $0.44^{*}$ & 0.19 & $-0.53^{*}$ & 0.27 & $-0.93^{*}$ & $-0.42^{*}$ & 1 & & & \\
\hline $\mathrm{V}_{\mathrm{S}}$ & 0.10 & -0.11 & 0.23 & 0.25 & 0.18 & 0.11 & 0.15 & 0.09 & -0.18 & $0.32^{* *}$ & $0.41^{*}$ & 0.13 & $-0.45^{*}$ & 0.13 & $-0.99^{*}$ & $-0.61^{*}$ & $0.91^{*}$ & 1 & & \\
\hline$V_{M A}$ & -0.06 & -0.03 & -0.07 & -0.20 & -0.13 & -0.15 & -0.17 & -0.14 & 0.08 & -0.21 & $-0.33^{* *}$ & 0.04 & 0.24 & $-0.36^{* *}$ & $0.80^{*}$ & $0.36^{*}$ & $-0.85^{*}$ & $-0.81^{*}$ & 1 & \\
\hline $\mathrm{V}_{\mathrm{MI}}$ & -0.06 & $-0.38^{*}$ & $0.46^{*}$ & -0.12 & -0.22 & -0.27 & $-0.29^{* *}$ & -0.18 & $0.37^{*}$ & $-0.76^{*}$ & -0.20 & -0.14 & $0.29^{* *}$ & $-0.77^{*}$ & $0.54^{*}$ & -0.15 & $-0.47^{*}$ & $-0.50^{*}$ & $0.32^{\star *}$ & 1 \\
\hline $\mathrm{V}_{\mathrm{CRI}}$ & 0.00 & $0.56^{*}$ & $-0.70^{*}$ & 0.02 & 0.14 & $0.30^{* * *}$ & $0.30^{* *}$ & 0.21 & -0.25 & 0.63 & 0.04 & -0.04 & 0.00 & $0.99^{*}$ & -0.15 & $0.55^{*}$ & 0.23 & 0.10 & $-0.32^{* *}$ & $-0.77^{*}$ \\
\hline
\end{tabular}

$*$ : significant value, $\mathrm{p}<0.01 ; * *$ : significant value, $\mathrm{p}<0.05$.

As expected, the bivalent cations $\mathrm{Ca}^{2+}$ and $\mathrm{Mg}^{2+}$ were highly correlated with each other and with SB and CEC, whereas no correlation was found between $\mathrm{K}^{+}$and soil CEC. On the other hand, $\mathrm{Na}^{+}$was slightly but significantly correlated with soil CEC, despite the weak bonding with soil exchangeable complex and the very low content in weathered tropical soils (Gillman \& Bell, 1978; Lilienfein et al., 2000). The correlation is explained by the substantial $\mathrm{Na}^{+}$input into soil during irrigation with wastewater and sodic tap water (2.44 tons per ha over two years). The correlation between $\mathrm{Na}^{+}$and $\mathrm{K}^{+}$was significant but negative (-0.572), indicating a possible exchange between these two species in the soil CEC.

Correlations were predictable among the physical parameters, such as the correlation between residual soil water $\left(\theta_{\mathrm{R}}\right)$ and soil cryptoporosity $\left(\mathrm{V}_{\mathrm{CRI}}\right)$ or the negative correlation between gravitational water $\left(\theta_{\mathrm{S}}\right)$ and volume of soil solids $\left(\mathrm{V}_{\mathrm{S}}\right)$. A negative correlation was also found between $\theta_{\mathrm{R}}$ or $\mathrm{V}_{\mathrm{CRI}}$ and $\mathrm{V}_{\mathrm{MI}}$, i.e., an increase in cryptoporosity can negatively affect the capillary water content. Water content at field capacity (capillary water) was partially correlated with both volume of solids (-0.609) and cryptoporosity (0.545).

The dual effect of clay dispersion on soil porosity can be presumed from the opposite correlations between water dispersed clay (WDC) and $\mathrm{V}_{\mathrm{MI}}$ (negative correlation: -0.761) and between $\mathrm{WDC}$ and $\mathrm{V}_{\mathrm{CRI}}$ (positive correlation: 0.629), pointing to a change in the pore size distribution. These results can be interpreted as follows: (a) the clay dispersion induced by $\mathrm{Na}^{+}$caused a decrease of the inter-aggregate volume $\left(\mathrm{V}_{\mathrm{MI}}\right)$ and (b) the colloid expansion due to $\mathrm{Na}^{+}$diffusion caused an increase in the intra-aggregate volume $\left(\mathrm{V}_{\mathrm{CRI}}\right)$.

The saturated hydraulic conductivity $\left(\mathrm{K}_{\mathrm{SAT}}\right)$ was negatively correlated with $\mathrm{Ca}^{2+}(-0.589)$ and $\mathrm{Mg}^{2+}$
(-0.720) but not with $\mathrm{Na}^{+}$, although hydraulic conductivity is generally largely modified by $\mathrm{Na}^{+}$ (Frenkel et al., 1972; Scotter, 1985; Balks et al., 1998; Magesan et al., 1999; Meenner et al., 2001; Jnad et al., 2001; Shainberg et al., 2001; Bagarello et al., 2006). We explained this result by two parallel and independent processes: (a) high $\mathrm{Ca}^{2+}$ and $\mathrm{Mg}^{2+}$ contents in the surface of fertilized soils and decrease with depth, and (b) typical increase of $\mathrm{K}_{\mathrm{SAT}}$ with depth (compacted surface soil), also observed in the nonirrigated soil. On the other hand, the low correlation between $\mathrm{K}_{\mathrm{SAT}}$ and $\mathrm{Na}^{+}$could be due to $\mathrm{Na}^{+}$leaching during rainfall. These results call for a careful interpretation of the correlation data.

\section{Multivariate analysis}

The $\mathrm{R}$-mode factor analysis resulted in six extracted factors with eigenvalue greater than 1 (Table 5 and Figure 2). The first factor accounted for $31 \%$ of the total variance, and $\mathrm{V}_{\mathrm{CRI}}$ was the property with greatest contribution to this factor, with a loading of 0.93. High loading was also found for $\theta_{\mathrm{R}}, \mathrm{K}^{+}, \mathrm{V}_{\mathrm{MI}}$ $(>0.70)$ and for $\theta_{\mathrm{FC}}$ and WDC $(>0.60)$, and, consequently, this factor was called "Fine porosity".

Ion $\mathrm{Na}$ is considered a modifier of soil structure and porosity (Halliwell et al., 2001) when concentrations largely exceeds the concentration of bivalent ions. In this case, irrigation with $\mathrm{Na}^{+}$-rich wastewater would cause these expected changes. However, the loading of $\mathrm{Na}^{+}$in factor 1 was lower than of other properties, as $\mathrm{K}^{+}$, indicating that the latter would have more effect than $\mathrm{Na}^{+}$on soil fine porosity. Some studies reported the effect of $\mathrm{K}^{+}$on soil hydraulic conductivity, but $\mathrm{K}^{+}$-enriched wastewater (ex.: distillery effluent) was applied to soils (Arienzo et al., 2009). 
Table 5. Main extracted factors after varimax rotation

\begin{tabular}{|c|c|c|c|c|c|c|c|}
\hline Soil property & F1 & F2 & F3 & F4 & F5 & F6 & Comm. \\
\hline $\mathrm{H}+\mathrm{Al}$ & 0.01 & 0.08 & -0.07 & -0.99 & 0.05 & -0.01 & 1.00 \\
\hline $\mathrm{Na}^{+}$ & 0.48 & -0.11 & 0.47 & 0.10 & -0.01 & 0.07 & 1.00 \\
\hline $\mathrm{K}^{+}$ & -0.72 & 0.22 & -0.03 & 0.14 & 0.02 & -0.01 & 1.00 \\
\hline $\mathrm{Ca}^{2+}$ & -0.07 & 0.17 & 0.93 & 0.10 & 0.00 & -0.05 & 1.00 \\
\hline $\mathrm{Mg}^{2+}$ & 0.07 & 0.06 & 0.86 & -0.01 & 0.12 & -0.07 & 1.00 \\
\hline $\mathrm{SB}^{(1)}$ & 0.18 & 0.05 & 0.90 & 0.14 & 0.02 & 0.01 & 1.00 \\
\hline $\mathrm{CEC}^{(1)}$ & 0.18 & 0.08 & 0.88 & -0.21 & 0.04 & 0.01 & 1.00 \\
\hline $\mathrm{V}^{(1)}$ & 0.11 & 0.06 & 0.73 & 0.58 & 0.07 & -0.01 & 0.96 \\
\hline $\mathrm{K}_{\mathrm{SAT}}{ }^{(1)}$ & -0.19 & -0.02 & -0.30 & 0.12 & -0.02 & 0.02 & 0.50 \\
\hline $\mathrm{WDC}^{(1)}$ & 0.61 & 0.21 & 0.10 & 0.07 & 0.19 & -0.10 & 0.75 \\
\hline$\%$ sand & 0.00 & 0.30 & 0.03 & 0.00 & -0.14 & -0.94 & 1.00 \\
\hline$\%$ silt & -0.02 & 0.06 & 0.07 & -0.03 & 0.97 & 0.21 & 1.00 \\
\hline$\%$ clay & 0.01 & -0.31 & -0.09 & 0.02 & -0.73 & 0.60 & 1.00 \\
\hline$\theta_{\mathrm{R}}^{(1)}$ & 0.97 & 0.15 & 0.11 & 0.03 & -0.03 & 0.02 & 0.99 \\
\hline$\theta_{\mathrm{S}}{ }^{(1)}$ & -0.04 & -0.95 & -0.08 & 0.02 & -0.09 & 0.13 & 1.00 \\
\hline$\theta_{\mathrm{FC}}(1)$ & 0.61 & -0.61 & 0.05 & 0.02 & 0.01 & 0.00 & 0.86 \\
\hline $\mathrm{d}_{\mathrm{S}^{(1)}}$ & 0.13 & 0.92 & 0.11 & -0.05 & 0.17 & -0.19 & 0.96 \\
\hline $\mathrm{V}_{\mathbf{S}^{(1)}}$ & 0.00 & 0.96 & 0.08 & -0.02 & 0.08 & -0.13 & 1.00 \\
\hline $\mathrm{V}_{\mathrm{MA}}{ }^{(1)}$ & -0.22 & -0.90 & -0.08 & -0.01 & 0.08 & 0.05 & 1.00 \\
\hline $\mathrm{V}_{\mathrm{MI}}{ }^{(1)}$ & -0.73 & -0.37 & -0.10 & 0.02 & -0.12 & 0.09 & 1.00 \\
\hline $\mathrm{V}_{\mathrm{CRI}}{ }^{(1)}$ & 0.98 & 0.11 & 0.09 & 0.02 & -0.04 & 0.01 & 1.00 \\
\hline Eigenvalue & 6.42 & 4.49 & 3.16 & 1.62 & 1.47 & 1.13 & \\
\hline $\begin{array}{l}\% \text { cumulative } \\
\text { Variance }\end{array}$ & 31 & 52 & 67 & 75 & 82 & 87 & \\
\hline
\end{tabular}

\footnotetext{
(1) See table 2 .
}

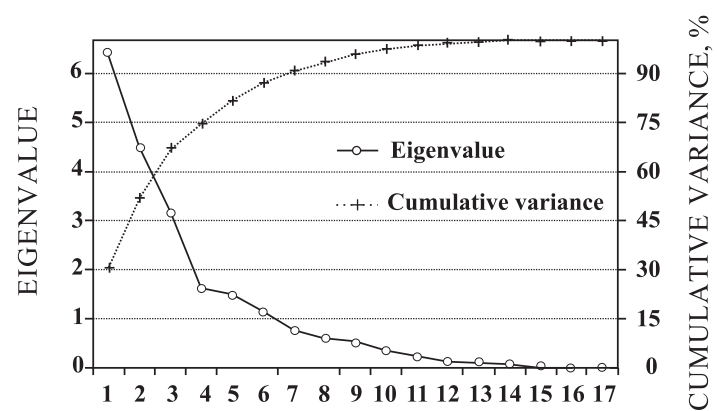

Figure 2. Eigenvalues of all extracted factors and cumulative variance.

Another interpretation mentioned above is possible: initially, high $\mathrm{Na}^{+}$concentrations in the soil solution forced an exchange with $\mathrm{K}^{+}$, and consequently $\mathrm{K}^{+}, \mathrm{Na}^{+}$and changes in soil porosity caused by $\mathrm{Na}^{+}$ were highly correlated. Then, $\mathrm{Na}^{+}$was leached during rainfall while $\mathrm{K}^{+}$remained partially bonded to soil clay particles, due to higher ionic bond forces. This scenario explained the appearance of a bias due to indirect factors (intense precipitations) not included in the multivariate analysis.

This demonstrates that $\mathrm{K}^{+}$content values can be used as an effective indicator of the degree of soil structure alteration. The advantage is that it could be employed independently of the season of the year once the $\mathrm{K}^{+}$content is less influenced by rainfall than $\mathrm{Na}^{+}$.
The second factor, called "Large porosity", represented the decrease of water content and increase of soil bulk density when macroporosity decreases (negative loadings for $\mathrm{V}_{\mathrm{MA}}, \theta_{\mathrm{S}}$ and $\theta_{\mathrm{FC}}$ and positive loadings for $V_{S}$ and $d_{A}$ ). No relation was observed between macroporosity and chemical parameters and therefore, we concluded that these soil physical properties are independent from the chemical changes after irrigation with wastewater.

The third factor, called "Soil CEC", consisted mainly of $\mathrm{Ca}^{2+}(0.93), \mathrm{Mg}^{2+}(0.86)$ and the exchangeable ionic complex properties that are characterized by CEC, SB and V (all loadings > 0.70). This factor was also slightly affected by $\mathrm{Na}^{+}$, although the high mobility of this ion through the soil profile may hide the actual effect of $\mathrm{Na}^{+}$on soil CEC. No significant contribution from the soil physical properties (all $<0.11$, except $\mathrm{K}_{\mathrm{SAT}}$ ) was observed.

The other four extracted factors, accounting for only $20 \%$ of the total variance, are factors with only one main property and can therefore be considered secondary factors. The fourth factor was "Soil acidity" (property H + Al); "Soil texture": clay and silt contents appeared together in the fifth factor, while the sixth factor included only sand content.

Fifteen of the 21 properties had a communality (proportion of variance of each property described by the totality of the extracted factors) equal to 1 , which 
means that the extracted factors are sufficient to explain their variability. On the other hand, the low communality for hydraulic conductivity indicates that a large part of its variance (50\%) was not explained by the factors, as indicated by the low loadings among the six factors. These results show the complexity of this soil property which depends on other, not studied soil properties such as tortuousity, grain shape, soil cracks, microfauna, root density.

\section{Effect of irrigation and soil depth on factor scores}

The factor scores are the coefficients of linear combination with the value of the new variable (factor) calculated from the studied properties for each sample. Analysis of variance indicated that irrigation was significant for the factor "Fine porosity" and also slightly significant for "Large porosity" (Table 6). The shift from large porosity (factor 2) to fine porosity (factor 1) is apparent when scores before irrigation (Figure 3a) and after irrigation with wastewater (Figure 3c) or with tap water (Figure 3b) are compared. This change in soil pore distribution highlights an increase in water storage (higher $\theta_{\mathrm{FC}}$ ) but, at the same time, higher retention due to two phenomena: higher capillarity force and $\mathrm{Na}$-induced, enhanced osmotic potential. The variation of both "Fine porosity" and "Large porosity" was greater after irrigation with sodic tap water than with wastewater. Despite the lower sodium concentration in tap water (103 $\left.\mathrm{mg} \mathrm{L}^{-1}\right)$ than in wastewater $\left(128 \mathrm{mg} \mathrm{L}^{-1}\right)$, the former presented higher sodicity risk due to low $\mathrm{Ca}^{2+}$ and $\mathrm{Mg}^{2+}$ concentrations and consequently high Sodium Absorption Ratio (SAR $=\left[\mathrm{Na}^{+}\right] /\left(\left[\mathrm{Ca}^{2+}+\right.\right.$ $\left.\mathrm{Mg}^{2+}\right]^{-1 / 2}$, concentration values in $\left.\mathrm{mmol} \mathrm{L}^{-1}\right)$.

The factors "Fine porosity" and "Large porosity" did not significantly differ within the soil profile (Table 7). On the other hand, depth had an important effect on factors 3 and 4 (as shown in Figure 2b,c) due to the higher soil retention capacity in the upper organic horizons.

Table 6. Effect of irrigation on factor scores. Plot SW: soil irrigated with sewage wastewater; plot PW: soil irrigated with sodic tap water; plot C: initial soil

\begin{tabular}{ccccccc}
\hline Plot & F1 & F2 & F3 & F4 & F5 & F6 \\
\hline SW & $0.50 \mathrm{a}^{(1)}$ & $-0.01 \mathrm{ab}$ & $-0.18 \mathrm{a}$ & $-0.15 \mathrm{a}$ & $-0.51 \mathrm{~b}$ & $0.34 \mathrm{a}$ \\
PW & $0.64 \mathrm{a}$ & $-0.37 \mathrm{~b}$ & $0.26 \mathrm{a}$ & $0.01 \mathrm{a}$ & $0.39 \mathrm{a}$ & $-0.20 \mathrm{a}$ \\
C & $1.09 \mathrm{~b}$ & $0.28 \mathrm{a}$ & $-0.04 \mathrm{a}$ & $0.12 \mathrm{a}$ & $0.01 \mathrm{~b}$ & $-0.05 \mathrm{a}$ \\
\hline
\end{tabular}
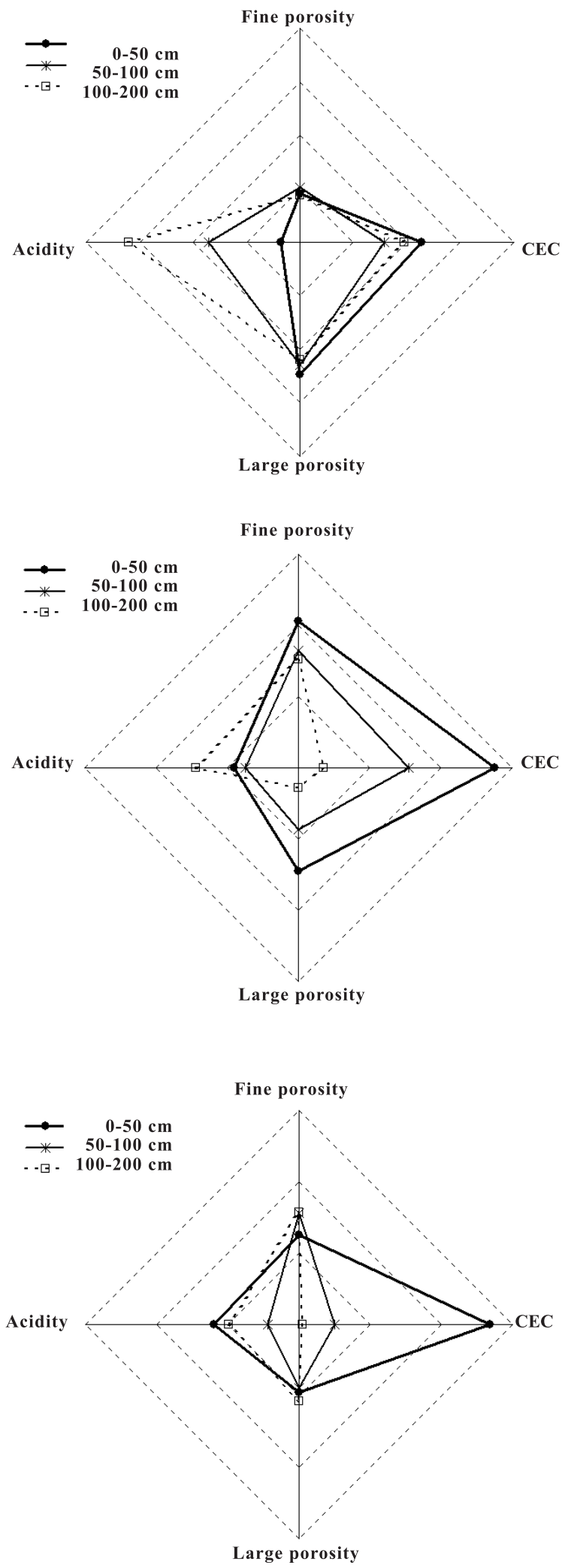

Figure 3. Factor scores in the soil layers 0-50, 50100 and $100-200 \mathrm{~cm}$, in non-irrigated soil (3a), irrigated with sodic tap water (3b) and irrigated with wastewater (3c). "Fine porosity": factor 1; "Large porosity": factor 2; "Soil CEC": factor 3; "Acidity": factor 4. 
Table 7. Effect of soil depth on factor scores

\begin{tabular}{rrrrrrr}
\hline Depth & F1 & F2 & F3 & F4 & F5 & F6 \\
\hline $\mathrm{cm}$ & & & & & & \\
12.5 & $0.10 \mathrm{a}^{(1)}$ & $0.36 \mathrm{a}$ & $1.45 \mathrm{a}$ & $-0.30 \mathrm{ac}$ & $0.21 \mathrm{a}$ & $-0.40 \mathrm{a}$ \\
37.5 & $0.01 \mathrm{a}$ & $0.22 \mathrm{a}$ & $0.86 \mathrm{ac}$ & $-0.87 \mathrm{a}$ & $-0.44 \mathrm{a}$ & $0.58 \mathrm{a}$ \\
62.5 & $-0.05 \mathrm{a}$ & $-0.37 \mathrm{a}$ & $-0.06 \mathrm{bc}$ & $-0.48 \mathrm{ac}$ & $0.16 \mathrm{a}$ & $-0.75 \mathrm{a}$ \\
87.5 & $0.17 \mathrm{a}$ & $0.26 \mathrm{a}$ & $-0.17 \mathrm{bc}$ & $-0.30 \mathrm{ac}$ & $0.14 \mathrm{a}$ & $0.44 \mathrm{a}$ \\
112.5 & $-0.17 \mathrm{a}$ & $-0.19 \mathrm{a}$ & $-0.21 \mathrm{bc}$ & $-0.05 \mathrm{abc}$ & $-0.57 \mathrm{a}$ & $0.03 \mathrm{a}$ \\
137.5 & $-0.02 \mathrm{a}$ & $0.08 \mathrm{a}$ & $-0.67 \mathrm{~b}$ & $0.48 \mathrm{cb}$ & $0.14 \mathrm{a}$ & $-0.44 \mathrm{a}$ \\
162.5 & $0.33 \mathrm{a}$ & $0.10 \mathrm{a}$ & $-0.60 \mathrm{~b}$ & $1.05 \mathrm{~b}$ & $0.32 \mathrm{a}$ & $0.59 \mathrm{a}$ \\
187.5 & $-0.24 \mathrm{a}$ & $-0.72 \mathrm{a}$ & $-0.47 \mathrm{~b}$ & $0.44 \mathrm{abc}$ & $-0.26 \mathrm{a}$ & $0.20 \mathrm{a}$ \\
\hline (1) Same letters mean no significant difference between plots.
\end{tabular}

\section{CONCLUSION}

1. Multivariate analysis resulted in three main factors: F1-"Fine Porosity", F2-"Large Porosity" and F3-"CEC", and three minor factors: F4-" Acidity" and F5/F6-"Soil texture".

2. Wastewater irrigation has antagonist effects on F1 and F2: an increase of fine porosity (pore diameter $<50 \mu \mathrm{m}$ ), correlated with soil exchangeable $\mathrm{K}^{+}$, was identified, while large porosity decreased.

3. Exchangeable $\mathrm{K}^{+}$was indirectly influenced by the great input of $\mathrm{Na}^{+}$through wastewater. This ion can therefore be used as an indicator of quality alterations of wastewater irrigated soils.

\section{LITERATURE CITED}

ARIENZO, M.; CHRISTEN, E.W.; QUAYLE, W. \& KUMAR, A. A review of the fate of potassium in the soil-plant system after land application of wastewaters. J. Haz. Mat., 164:415-422, 2009.

AYERS, R.S. \& WESCOT, D.W. Water quality of agriculture. Roma, Food and Agriculture Organization, 1985.174p.

BAGARELLO, V.; IOVINO, M.; PALAZZOLO, E.; PANNO, M. \& REYNOLDS, W.D. Field and laboratory approaches for determining sodicity effects on saturated soil hydraulic conductivity. Geoderma, 130:1-13, 2006.

BALKS, M.R.; BOND, W.J. \& SMITH, C.J. Effects of sodium accumulation on soil physical properties under an effluent-irrigated plantation. Austr. J. Soil Res., 36:821830, 1998.

BHARDWAJ, A.K.; GOLDSTEIN, D.; AZENKOT, A. \& LEVY, G.J. Irrigation with treated wastewater under two different irrigation methods: Effects on hydraulic conductivity of a clay soil. Geoderma, 140:199-206, 2007.

BOND, W.J. Wastewater irrigation - an environmental challenge for soil science. Austr. J. Soil Res., 36:543-555, 1998.

FRENKEL, H.; GOERTZEN, J.O. \& RHOADES, J.D. Effects of clay type and content, exchangeable sodium percentage, and electrolyte concentration on clay dispersion and soil hydraulic conductivity. Soil Sci. Soc. Am. J., 42:32-39, 1972.
GILLMAN, G.P. \& BELL, L.C. Soil solution studies on weathered soils from tropical North Queensland. Austr. J. Soil. Res., 16:67-77, 1978.

GLOAGUEN, T.V.; FORTI, M.-C.; LUCAS, Y.; MONTES, C.R.; GONÇALVES, R.A.B.; HERPIN, U. \& MELFI, A.J. Soil solution chemistry of a Brazilian Oxisol irrigated with treated sewage sludge. Agric. Water Manag., 88:119-131, 2007.

HALLIWELL, D.J.; BARLOW, K.M. \& NASH, D.M. A review of the effects of wastewater sodium on soil physical properties and their implications for irrigation systems. Austr. J. Soil. Res., 39:1259-1267, 2001.

JAYAWARDANE, N.S.; BISWAS, T.K.; BLACKWELL, J. \& COOK, F.J. Management of salinity and sodicity in a land FILTER system, for treating saline wastewater on a saline-sodic soil. Austr. J. Soil. Res., 39:1247-1258, 2001.

JNAD, I.; LESIKAR, B.; KENIMER, A. \& SABBAGH, G. Subsurface drip dispersal of residential effluent: I. Soil chemical characteristics. Trans. Am. Soc. Agron. Eng., 44:1149-1157, 2001a.

JNAD, I.; LESIKAR, B.; KENIMER, A. \& SABBAGH, G. Subsurface drip dispersal of residential effluent: II. Soil hydraulic characteristics. Trans. Am. Soc. Agron. Eng., 44:1159-1165, 2001b.

KLUTE, A. \& DIRKSEN, C. Methods of soil analysis.: Physical and mineralogical methods. Madison, American Society of Agronomy \& Soil Science Society of America, 1986. Part 1. 1188p.

LILIENFEIN, J.; WILCKE, W.; LIMA, S.C.; VIVELO, L.; THOMAS, R. \& ZECH, W. Nutrient concentrations in soil solution of some Brazilian Oxisols under conventional and no-tillage systems in the early part of the rainy season. Austr. J. Soil. Res., 38:851-866, 2000.

MAGESAN, G.N.; WILLIAMSON, J.C.; SPARLING, G.P.; SCHIPPER, L.A. \& LLOYD-JONES, A.R. Hydraulic conductivity in soils irrigated with wastewaters of differing strengths: Field and laboratory studies. Austr. J. Soil. Res., 37:391-402, 1999.

MEENNER, J.C.; MCLAY, C.D.A. \& LEE, R. Effects of sodiumcontaminated wastewater on soil permeability of two New Zealand soils. Austr. J. Soil. Res., 39:877-891, 2001.

OSTER, J.R. \& SHAINBERG, I. Soil response to sodicity and salinity: Challenges and opportunities. Austr. J. Soil. Res., 39:1219-1224, 2001.

SCOTTER, D.R. The effect of electrolyte solutions on the unsaturated hydraulic conductivity of a sodic clay soil. Austr. J. Soil Res., 23:301-307, 1985.

SHAINBERG, I.; LEVY, G.J.; GOLDSTEIN, D.; MAMEDOV, A.I. \& LETEY, J. Prewetting rate and sodicity effects on the hydraulic conductivity of soils. Austr. J. Soil. Res., 39:1279-1291, 2001.

SHUKLA, M.K.; LAL, R. \& EBINGER, M. Determining soil quality indicators by factor analysis. Soil Till. Res., 87:194204, 2006.

TILLMAN, R.W. \& SURAPANENI, A. Some soil-related issues in the disposal of wastewater on land. Austr. J. Exper. Agric., 42:225-235, 2002.

van GENUCHTEN, M.T. A closed form equation for predicting the hydraulic conductivity of unsaturated soils. Soil Sci. Soc. Am. J., 44:892-898, 1980. 